\title{
A (NOT QUITE) FRIENDLY TREATY AND THE EU ENLARGEMENT IMPASSE
}

\begin{abstract}
:
The Friendship Treaty between Sofia and Skopje was one of the first foreign policy achievements of the newly formed Zoran Zaev-led government in 2017. It was presented as a closure of the long-lasting bilateral dispute between the two neighbouring countries, which would remove one obstacle on the way to EU integration. However, the subsequent Prespa agreement (signed almost a year later) took all the glory and public attention. The Friendship Treaty's real political weight and imperfections became obvious only in December 2020, when the Bulgarian veto prevented the opening of the negotiation process for the country. The article analyses and evaluates the Treaty and its implication through the political and legal lenses. The basic premise is that instead of paving the way to the full EU membership, the hastily signed agreement proved to be not only a new obstacle on the road but also a factor of deepening mutual distrust and tensions between the two peoples. The twist with the introduction of the new methodology of EU enlargement along with the Bulgarian veto makes the Balkan entanglement even more complex. The Macedonian state is back to square one, just like in the dispute with Greece, now being knotted with another bilateral dispute and identity issues that have nothing to do with good neighbourly relations and/or Copenhagen criteria. Conversely, this downplayed dispute may have a strong impact on the Macedonian state's viability in the mid-and long run. The key conclusion is that the stalemate of the EU enlargement process is at the same time a cause and a consequence of Brussel's inability to understand and resolve the protracted conflicts in the Balkans as well as a proof that EU membership is not a panacea for the age-old nationalism and chauvinism.
\end{abstract}

Keywords: TREATY OF FRIENDSHIP, GOOD-NEIGHBORLINESS, AND COOPERATION BETWEEN THE REPUBLIC OF MACEDONIA AND THE REPUBLIC OF BULGARIA, PRESPA AGREEMENT, EUROPEAN UNION, ENLARGEMENT

\section{Introduction}

The conventional wisdom is that the Republic of Macedonia's bids to join NATO and EU had been thwarted by the Greek veto for almost three decades. The 'name dispute' was seen as a crucial impediment, which intermittently overshadowed the other far more substantive internal deficiencies in terms 
of democratic, legal, and economic reforms. Likewise, it eclipsed the far more sensitive bilateral dispute with Sofia, which had been wrongly seen as rather unchallenging to resolve. Once the name issue was seemingly resolved through the Prespa Agreement (PA) there was a false expectation that the way to Brussels has been cleared and the reward will come soon. Nevertheless, first, it was the French president Macron who disillusioned the Euro-optimists in the Western Balkans in the fall of 2019, which even provoked a political crisis that eventually resulted in early parliamentary elections in 2021.

The Bulgarian veto of December 2020 came as a shock particularly to the advocates of the PA, which only proved their naiveté and/or short-sightedness. For instance, it took three years for an esteemed scholar (as well as a member of the Macedonian Academy of Sciences and Arts) such as Viktor Friedman to finally see the interlocking and interblocking details of the two agreements. In a recent piece, he argues:

... perhaps the most insidious part of the PA is the result that by opening the way to North Macedonia's membership in the EU it has also opened the way for Bulgaria to pursue its denialist policies toward the Macedonian language and to lay claim to all its dialects... In this sense, the PA settles a local quarrel that is seen in global terms, while the real global threat to the Macedonian language and linguistic scholarship comes from Bulgaria, which is outside the terms of the agreement, and which is under no constraint to behave according to so-called European values with respect to Macedonian. (Friedman, 2021).

The lingering conflict with Bulgaria preceded Macedonia's independence. Yet, few really paid attention to the conflict potential or underestimated it, to say the least. It was vastly ignored due to two basic reasons: first, during Yugoslavia's time, socialist Macedonia was protected within the federation with high international standing and experienced diplomacy, while Bulgaria was but a Soviet satellite. Secondly, even though Yugoslavia fall apart, post-communist Bulgaria remained weak in international affairs, so it could not show muscles in its near neighbourhood or elsewhere. Actually, she had been going through a serious political and economic crisis, also having faced its own wrangles in the EU accession process. Furthermore, Bulgaria had to prove its capacity to sustain good neighbourly relations both with the EU and non-EU states in the immediate region. Eventually, she became a NATO member in 2004, while the EU membership was achieved after an additional painstaking process of internal reforms, not in 2004 as planned, but in 2007 in a tandem with Romania. Sofia's (geopolitical) power towards Macedonia augmented throughout the years but the superiority was demonstrated in full force only after the Prespa Agreement.

Ever since December 2020, Bulgaria has taken over the role that Greece played for three decades. This position has been predetermined by the so-called new methodology of EU enlargement, which de facto enabled the greater influence of each nation-state in the decision-making and evaluation process and on 
each step of the way. The new methodology first strives to improve the effectiveness of positive conditionality, and then to introduce the possibility to halt or reverse the accession process if there is 'any serious or prolonged stagnation or even backsliding in reform implementation'. But Ćemalović (2020 p. 186) rightly points out a worrying aspect: i.e. the potential lack of uniform interpretation by the Commission (and the Member States) of whether some conditions are met or not. In this context, he takes into account refurbished authoritarian tendencies in some EU countries (dubbed 'illiberal democracies and populist regimes). This ambiguity had already been displayed in the Macedonian case, even before the official start of the negotiations as well as on the onset of the implementation of the new methodology.

For the purposes of this research, all available academic, all available academic databases and online libraries were thoroughly researched with the intention of making a literature review of any academic or expert analysis that deals with the first of the two bilateral (friendship) treaties signed by the Macedonian government i.e. Treaty of Friendship, Good-neighborliness, and Cooperation between the Republic of Macedonia and the Republic of Bulgaria (1 August 2017) and Final agreement for the settlement of the differences as described in the United Nations Security Council resolutions 817 (1993) and 845 (1993), the termination of the Interim Accord of 1995, and the establishment of a strategic partnership between the parties (better known as Prespa Agreement). Up to the time of writing this article, there has been not a single academic piece that would exclusively focus on the treaty with Bulgaria and/or its interrelatedness with the PA. On the contrary, the bibliography concerning the PA is growing rapidly (to mention just a few: Chryssogelos and Stavrevska 2019; Neofotistos 2021; Vlachov 2020; Loizides 2020; Heraclides 2020; Vankovska 2020; Maatsch \& Kurpiel 2021; Armakolas and Siakas 2021). It seems that the interest of academia followed the inertia of the false belief that the only issue that prevented Macedonia's accession process to the EU was the name dispute. The second reason is the augmented international involvement and media publicity related to the PA. The prior EU Commission listed the PA as one of its five top foreign policy achievements, while the Western media spoke of a miracle and closure of a long-lasting Balkan dispute. In sum, the so-called Bulgarian Agreement (BA) (as the treaty has been dubbed in the Macedonian public) had been treated like an 'orphan', a second-rate and less important foreign policy achievement of the Macedonian government.

Bearing in mind that the Bulgarian-Macedonian (frozen) conflict has always been protracted and thus more complex than the "name dispute", this article offers a brief background of the path to the Friendship treaty and makes a content analysis of its provisions. At last, it offers some conclusions on the present and future repercussions of the BA in view of the EU's enlargement. 


\section{The Express Path to the Friendship Treaty}

Bulgaria was the first state to formally recognize the independent Republic of Macedonia in February 1992 (along with Slovenia, Croatia, and Bosnia and Herzegovina), right after the positive opinion of the European Arbitrary (Badinter) Commission. Apparently, it was a gesture of unprecedented friendship, especially at the time when few believed that the tiny new state would survive Yugoslavia's dissolution. The testimony of the first non-communist Bulgarian president offers an interesting insight into the dubious and discordant internal policy-decision process and particularly of the government's initial intention to attend a conference of foreign ministers of Greece, Serbia, and Bulgaria in order to discuss Macedonia's future (Zhelev 2006). A Bulgarian historian Chavdar Marinov rightly points out that the recognition of Macedonian independence was dubious in itself. According to him, the Bulgarian elite almost immediately started reiterating the postulates of communist (Todor Zhivkov's time): i.e. the Macedonian nation is "created artificially" and on the grounds of the Bulgarian ethnicity that existed in Vardar Macedonia; the Macedonian language is a Bulgarian dialect, which was intentionally altered under the imposed Serbian influence; both states allegedly had "shared history", while the "population" of the Republic of Macedonia should acknowledge the "facts" and the "historical realities" (Marinov 2020, pp. 226-227, Macedonian edition). Furthermore, Marinov detects that this rhetoric reveals the loose irredentist aspect of the political act of Sofia. But in 1991-1992, the Republic of Macedonia did not have much choice but to follow the old saying "don't look a gift horse in the mouth" with respect to anyone's friendly gesture.

Certain historical reflection is necessary here, even though the author does not intend to go back to times when Macedonia was known as the "apple of discord" and "Balkan powder barrel" in the late $19^{\text {th }}$ and early $20^{\text {th }}$ century (see more Vankovska 2015). The crux of the matter is that for both today's Bulgaria and Greece

"the Macedonian nation is nonexistent and the people who feel they are Macedonians are just Bulgarians. In Greece, on the other hand, the dominant view is that a nation composes a 'tribal' group and, therefore, its members do not have the right to belong to such a nation, as they are not 'tribal' descendants of the ancient Macedonians". (Christopoulos and Karpozilos 2018, p. 42).

It is hardly a coincidence that the greatest national holiday of Bulgaria is 3 March, i.e. the day of signing the so-called San Stefano Treaty (1878), i.e. the one-day lasting Greater Bulgaria. Bulgaria is the only European country that celebrates something that is associated with overtly irredentist (territorial and ethnic) aspirations. In the dominant narrative, Macedonia is the never forgotten 'lost part' of the homeland and nationhood. Although this article does not deal with the historical background of Bulgarian-Macedonian relations, it is worth mentioning that the Bulgarians fought four wars (and lost them all) for the sake 
of Macedonia/Macedonians. In the words of the former Bulgarian president, Petar Stojanov, Macedonia is the most romantic part of Bulgarian history, and that's why Bulgaria cannot give it up. This statement echoed recently in the words of the former defense minister Karakachanov, who added: "Macedonia is not only the most romantic but also the most tragic part of Bulgarian history" (Plusinfo 2021). At the 2019 NATO summit, President Radev stressed that protecting the Republic of North Macedonia's airspace was Bulgaria's national duty and responsibility. In his words, Bulgaria should not miss the historic opportunity to protect Macedonia's airspace (Novinite 2019). These words could be taken at face value for they come from a top politician and in the context of Bulgaria's claims over the Macedonian territory and people as something that belongs to it historically. A member of the Bulgarian Helsinki Committee, however, warns of the necessity to read political messages more carefully $(D W$, 14 August 2009):

"Stojanov's statement is very accurate and it should be read very carefully. Macedonia is such a great part of Bulgarian history that it is impossible to take it away. Everyone in the Bulgarian political life has determined how to make unification with Macedonia possible, and that is the key to everything that has been happening in the last 100 years plus, since San Stefano up to date. Stojanov's statement was neither in a form of aspiration nor in a form of identity denial; it was a fact. Only through dialogue, it is possible to overcome that sensitivity."

Despite the undeniably positive political and diplomatic gestures of Bulgaria vis-à-vis the new independent neighbor not only in 1991 but also later during the Greek embargo and the 2001 conflict, the historical legacy and national interests (seen as a historical constant) have always guided the official policy towards Macedonia. Significantly, quite early Bulgaria recognized a common interest with Greece concerning the Macedonians' minority rights in each country respectively. Bulgaria supported the Greek demands for Macedonia's constitutional revision in terms of the change of Article 49 that envisaged protection of the Macedonian minority in the neighboring states. Zhelev (ibid.) lobbied with the Macedonian president Kiro Gligorov to show understanding for this 'sensitive issue' for both Greece and Bulgaria. The two Balkan neighbors, who fought against each other during the Second Balkan war and the First World War, went through an operation of exchange of population in the bordering regions (which affected the Macedonian population as well) in 1919. According to Christopoulos and Karpozilos (ibid.), they settled a 'gentleman's agreement' to never speak of any minority in the future. Ever since they have ignored the issue in their mutual relations as if it never existed. Despite the consequent development of the international law on minority rights and the membership of the Council of Europe and other international forums, both countries have a poor record of protection of minority rights (including the one of the ethnic Macedonians). 
Under strong international pressure, Macedonia went through its first constitutional reform less than two months after the Constitution's adoption. The first two amendments were introduced to apparently please Greece and its EU allies. The first one essentially stipulates that the Republic of Macedonia guarantees that it does not have any territorial aspirations toward the neighboring states. The second amendment altered Article 49 that originally stipulated that "The Republic cares for the rights and the position of the Macedonian people living in neighboring countries and the Diaspora, helps their cultural development and supports ties with them." The amendment clarified that "by doing this, the Republic shall not interfere in the sovereign rights of other countries when it comes to their internal matters". The reference to "internal affairs" is just a euphemism for not advocating minority rights. Constitutionalists argued that this reform, carried out under external pressures (and before the country's admission to UN, which de facto equaled a blackmail and security threat), was humiliating and devalued "the democratic capacity of the Constitution" (Karakamisheva Jovanovska 2019, p. 6).

In addition to Bulgaria's sensitivity concerning the existence of the Macedonian minority, the second essential issue is language. The negotiations between Sofia and Skopje over the language clause started in the mid-1990s. The government of conservative (and allegedly, more patriotic) VMRO-DPMNE led by Ljubcho Georgievski signed a Joint Declaration with his Bulgarian counterpart Ivan Kostov in Sofia on 22 February 1999. In Skopje this move was seen as a shock: it was made hastily, within the first 100 days of the government, and with no consultations with the opposition and or the public. The Social-Democrats accused Georgievski of treason, while some high party officials argued that "we are going to become a nationally amorphous mass, with a state but with no national affiliation, and moreover with Bulgarian origins" (Призма 2020). President Gligorov addressed the parliament accusing the Government of a small coup d'état. The government boasted that it had found a 'final solution for the language dispute' and that the European prospects were realistic. The Declaration, otherwise full of empty diplomatic rhetoric of good neighborly relations, indeed centered on the following dubious premises:

"The Republic of Macedonia hereby declares that nothing in its Constitution can or should be interpreted as constituting, now or whenever in the future, a basis for interference in the internal affairs of the Republic of Bulgaria for the purpose of defending the status and the rights of persons who are not citizens of the Republic of Macedonia. The two countries shall undertake effective measures for preventing ill-intentioned propaganda by institutions and agencies and shall not allow activities by private individuals aimed at instigating violence, hatred, or other such actions which might harm relations between the Republic of Bulgaria and the Republic of Macedonia. Signed on 22 February 1999 in Sofia, in two originals, each in the official languages of the two countries 
- in Bulgarian, according to the Constitution of the Republic of Bulgaria, and in Macedonian, according to the Constitution of the Republic of Macedonia, both texts being equally authentic." (emphasis added by the author) (UN 1999).

Thus Skopje undertook an obligation to sanction any 'hostile speech or acts' against Bulgaria, which is particularly dubious when it applies to private citizens (and their freedom of speech). And finally, the apparently compromising language formula (equal for both sides) induced fears with respect to the internal challenges: i.e. the pressing demands for making Albanian the second official language. Eventually, the language rights of the ethnic Albanians became a matter regulated by the Ohrid Framework Agreement (and consequent constitutional changes of 2001), and at last with the 2018 Law on Use of Languages.

The 1999 Joint Declaration was reaffirmed by a joint memorandum signed on 22 January 2008 in Sofia. Yet the problems were far from resolved. According to a former Macedonian ambassador, Bulgaria insisted on transforming the allegedly unbalanced declaration into an inter-state treaty on good neighborly relations in 2014/2015. President Rosen Plevneliev addressed the Bulgarian ambassadors saying "the Treaty is our strategic priority and a condition for Bulgaria's support for the start of the EU membership negotiations" and "Macedonia should sign it ... and stop changing historical facts." (Quoted from Gaber 2017, pp. 353-354)

Nikola Gruevski's government (2006-2016) apparently continued negotiations with Sofia (as well as with Athens) but cautiously and at a snail's pace. Gruevski was not ready for any dramatic concessions - defense of Macedonianness was the key point of his ruling paradigm and ideology (including the counterproductive insistence on antiquity especially after the failure at the 2008 NATO summit). As he testified later, in July 2017, the Bulgarian demands his government had not been ready to accept concerned: the (non) recognition of the Macedonian language (or rather, the insistence that the Macedonian language is but a Western Bulgarian dialect), shared history (i.e. acknowledgment that the Macedonians did not exist before 1944), giving up the idea of the Macedonian minority in Bulgaria and revision of history books. (Hemnpec 2017). The same concerns were repeatedly confirmed by the former Minister of Foreign Affairs from VMRO-DPMNE, Nikola Popovski.

It took an internal political crisis, international involvement, and regime change to bring in a more cooperative government. Zaev quickly accepted everything that the VMRO-DPMNE government rebuffed. Contrary to the electoral program, one of the first foreign-policy priorities of the government was closing down the disputes with the neighbors. The first stop was Sofia: the path was almost completely paved by the previous government, and the deal was blocked only due to the disagreement over the most sensitive aspects. In a need for a speedy result at any cost, Zaev quickly agreed to all points that had previously been objected to. The negotiation process took less than a couple of 
months, with no expert or public debate whatsoever. The text of the preliminary agreement signed by the two prime ministers was kept in secrecy. The opposition and the experts called for transparency and warned about the possible harmful consequences of a hasty and inattentive treaty over the Macedonian identity - in vain. Zaev responded that the final decision would still be taken by the Parliament. In reality, on 18 July 2017, only the parliamentary commission on foreign affairs held a closed session. According to the members' testimonies, the treaty text was disclosed just hours prior to the session and the copies were collected back at the end in order not to be made public. The notes from the session are still not available for the public; the session was treated as highly confidential. The MPs were informed that the text was a draft document that could be improved eventually.

Eventually, what was said to be a draft text, at the end of the day appeared to be the final version. The agreement was signed on 1 August 2017, during Bulgarian Prime Minister Boyko Borissov's official visit to Skopje. At the occasion (just a day before the Macedonian national holiday Ilinden), Zaev said that the treaty is "a historic step forward for Macedonia and Bulgaria that shows that the past can be a basis for future cooperation". Borissov stated that "the treaty shows that even in the turbulent Balkans, problems can be solved through agreements and without foreign mediators" - an outcome which he said deserves high praise from Brussels (Balkan Insight 2017).

\section{What is Friendly in the Friendship Treaty?}

The BA was signed on a premiers' level in the capital Skopje. If it is to be judged by the treaty's title the two contracting parties are equal and named in accordance with their constitutions. The Republic of Macedonia appears as the first party. In terms of its content, the BA is a rather brief document: it consists of only 14 short articles (i.e. in total, less than five full pages of text).

At a glance, the BA appears as a rather vague treaty consisting of a list of good wishes in various domains of cooperation. All commitments are within the matters that are self-understandable for any sovereign and responsible members of the UN, OSCE, Council of Europe, etc. A good example for the pleonastic feature of the Treaty is to be found in Article 11 para 3, which reads: "The two Contracting Parties do not hold and will not manifest any territorial claims against each other." Again, it seems ridiculous to expect two European countries to put in writing that they do not harbor any territorial aspirations, especially keeping in mind that one of them at the time was one of the militarily weakest states in the world, while the other was a NATO member state. But few truly believed that this Treaty was about something else than the identity package of issues.

It did not call for a careful reading of the Treaty's preamble to detect the prospective 'landmine', which referred to "taking account of the shared history that ties together the two countries and their peoples". As the implementation 
of the Treaty has already proved, the so-called shared history does not imply shared Balkan history, but rather a mutual history of the Bulgarians and Macedonians. The concept of shared history is hardly elaborated in academia, but things get even worse when taken into the semiotic context of each language and the state of affairs that may be explained as lost in transition. Hence what is unofficially translated as shared history in the Treaty's English version provided by the Macedonian Foreign Ministry, in Macedonian is called заедничка историја. In Bulgarian, it reads 'обща', which is translated into common or заедничка (history). The Treaty is signed in Macedonian and in Bulgarian, which means that there is no official English version to clarify if the contracting parties had in mind common or shared history. Only through the practice, one could see that the treaty was drafted and signed based on a mutual misunderstanding - or the weaker side's naiveté.

The Articles 4-7 each envisage a wide scope of cooperation in enlisted fields: political one (political communication on a national and local level), economics (enabling as free as possible movement of goods, services, and capital, encouragement of joint investments and their protection), tourism, build-up of transportation, communication, and regional infrastructure, and facilitation of customs and border formalities for passengers and goods. The rather brief provisions also sound like wishful thinking on both sides, especially bearing in mind their limited economic potentials in both countries that could implement some of these projects only through further indebtedness with international creditors and making priorities within the limited state budgets.

Eventually, the crux of the matter (i.e. the real reason for signing the treaty) is to be found in a couple of articles that are quite bizarre: Article 8 para 2 and para 3 and Article 11 para 5. These provisions deal with the most sensitive (identity-related) issues that have been haunting the relations between the two states and peoples. They are meant to be skillfully masked in a lot of reiterations of international norms and a veil of friendship. The wording is apparently well-balanced to leave an impression of a symmetrical treaty between equal parties. However, the power relations and supremacy of Bulgaria are visible in a few instances. The most observable one is the wording of the provision in Article 11 para 5 that reads:

"The Republic of Macedonia hereby confirms that nothing in its Constitution may be and should be interpreted in a way that it constitutes or shall ever constitute the basis for interference in the internal affairs of the Republic of Bulgaria, with the purpose of protecting the status and rights of persons who are not nationals of the Republic of Macedonia."

Not only is the matter obsolete, bearing in mind the aforementioned 1992 amendments to the Constitution, but this is the only occurrence in the text where the Macedonian party is explicitly pointed out as a potential violator of the basic international norm of non-interference in sovereign states' internal affairs. Again, it seems that the smallest and weakest neighbor of Bulgaria 
(and Greece) represents a threat in terms of affirmation of any minority rights. Interestingly, even though neither Article 11 of the Treaty, nor any other of the Treaty provisions refers to minorities or minority rights, it is self-understanding that this provision is implicitly meant to apply to all Bulgarian citizens of with Macedonian ethnic belonging (persons who are not nationals of the Republic of Macedonia). In this respect, Article 11 is contrary to the preamble that states that it relies on the principles of international law (the UN Charter, the OSCE documents and the "democratic principles contained in the CoE acts") (Ristevska Jordanova and Kacarska 2020, p. 9). While pleading on international norms, the treaty insists on denial of the rights of the persons belonging to minorities, which are undeniable and also one of the values of the EU (Treaty on European Union art 2). The key issue here is not the position or behavior of any neighboring country, but the very fact that Bulgaria as a state has an obligation for safeguarding the rights of minorities in the countries. The CoE documents have noted numerous instances of non-recognition of the Macedonian minority by Bulgaria (Parliamentary Assembly of the Council of Europe 2019) and non-obliging to judgments of the Court of the organizations aiming to achieve "the recognition of the Macedonian minority in Bulgaria (The Commissioner for HR 2020).

The other central provision of the Treaty is in Article 8, which reads:

1. The two Contracting Parties shall encourage their active and unimpeded cooperation in areas of culture, education, health care, social policy, and sports.

2. With a view to strengthening their mutual trust, within three months at the latest from the entry into force of this Treaty, the two Contracting Parties shall establish a Joint Multidisciplinary Expert Commission on Historical and Education Issues, aiming to contribute to objective, scientific interpretation of historical events, founded on authentic and evidence-based historical sources. The Commission shall submit an annual report about its work to the Governments of the two Contracting Parties (emphasis added by the author).

3. Upon mutual agreement, the two Contracting Parties shall organize joint celebrations of shared historical events and personalities, with the aim of strengthening their good-neighborly relations, in the spirit of European values."

Para 1 refers to unimpeded cooperation (whoever impeded the free cooperation between sovereign states where freedom of association is a must and beyond State's power remains an enigma). The cooperation scope explicitly refers to culture, education, health care, social policy, and sports. Yet the following paragraphs (2 and 3) regulate only historical and educational issues. Most importantly they envisage establishing a Multidisciplinary Expert Commission that is to contribute to "objective, scientific interpretation of historical events, founded on authentic and evidence-based historical sources". Obviously, from the onset, the commission was imagined as a state-formed and sponsored body (made of experts, according to the liking of each state and on a parity principle). It is 
supposed to report to the governments of the contracting parties. Thus, miraculously, the expert commission that is supposed to follow objective and scientific methodology turns into a body that is responsible for its work (i.e. advancement in the process) to the government(s). The last paragraph (3) indirectly elaborates the purpose of this commission's work: organizing celebrations of shared historical events and personalities. The key concept here is again shared history, which remains dubious and subject to different interpretations. It is only from the commission's name that one could tacitly conclude that there is one more goal of its work: education in the field of history (nothing about health, sport, and social policy, however).

The end result of the Friendship Treaty between the two states is a clear violation of human rights, which became collateral damage to the regional peace and stability and the EU enlargement. In addition to the minority rights' denial, the BA assumes state(s) control over freedom of thought, the autonomy of academic work and research (particularly in the field of history and linguistics), freedom of speech and association, etc.

Interestingly, Sofia insists on shared history, while Athens on the contrary insists on the demarcation of history. Sofia's primary goal is to 'prove' the sameness of the historical grounds and origin of the two populations, while Athens focuses on 'attestation' of its continuity myth from antiquity (i.e. Alexander the Great) up to the present. Greekness and Bulgarianness of the states differ because the latter tends to be all-inclusive (absorbing the Macedonians, who happened to form a statehood and become a political community by historical misfortune). The politicization of Macedonian historiography and historical research is obvious and under pressure from state authorities from all three (i.e. including the Macedonian one) sides simultaneously. The former Greek foreign minister Nikos Kotzias (2020) argues that the "Macedonian" issue started off as an intra-Slavic conflict: "With the Prespa Agreement, Greece got rid of the problem. An agreement that was literally 'envied' by the diplomatic establishment in Sofia. This happened despite the fact that they were the first to sign a "Friendship Pact" with North Macedonia". Also, a former Macedonian ambassador to Sofia argues that many in Bulgaria believe that the Greek deal with Skopje was better and more skillfully designed (Spasov 2019). Thus no wonder there are so many initiatives for the Treaty's revision and/or extension.

Opposite to the widespread opinion that only the PA is asymmetrical, i.e. that the BA is fairer, the analysis shows a different story. The BA equally reflects the incomparable power misbalance between the contracting parties even though in a more subtle way. The only 'obligation' of the Bulgarian side undertaken by this Treaty is written down in Article 2 para 2:

The Bulgarian side shall share its experiences in order to help the Republic of Macedonia fulfill the criteria required for membership of the European Union, and shall support the Republic of Macedonia in obtaining an invitation for membership of NATO, in accordance with relevant decisions adopted at NATO summit meetings. 
A careful reading shows that Bulgaria was only fully committed to Macedonia's entry into NATO - something that was understandable, bearing in mind the strong military ties of Sofia and Washington and the inability to oppose the superpower (Vankovska 2020a). When it comes to the EU enlargement, this provision only stipulates that Bulgaria is going to assist by sharing its experiences in fulfilling the criteria required for membership of the Union. Bearing in mind all the troubles that Bulgaria had and still has with respect to these criteria, this is obviously just a lip-service. For instance, Radosveta Vassileva (2021) convincingly showcases how Bulgaria has not resolved any of the country's longstanding challenges to the rule of law, democracy, and wellbeing since it joined the EU. Ironically, she argues that one "may wonder if the country has not joined the wrong Union by mistake", especially having in mind Politico's claim that Bulgaria is a mafia state (9 September 2020). In the light of Sofia's veto, this looks like an ironic twist of destiny and creates a déjà vu feeling of the times when the Republic of Macedonia was blocked by Greece despite the provisions of the 1995 Interim Agreement.

One could argue that the BA respects the equality of the contracting parties and does not have ambitions to make it 'eternal' and irrevocable. Article 13 reads:

1. This Agreement is subject to ratification in accordance with the constitutional requirements of the Contracting Parties. This Agreement shall enter into force on the date of the exchange of instruments of ratification by both Contracting Parties and shall remain in force indefinitely.

2. This Agreement may be amended by written consent between the two Contracting Parties. The amendments shall be negotiated diplomatically and shall enter into force in accordance with paragraph 1 of this Article.

3. Either Contracting Party may terminate the Agreement by sending written

4. notice to the other Contracting Party. The Agreement shall cease to be in force one year after the date of receipt of such notification.

In other words, the BA is originally meant to remain in force indefinitely, i.e. as long as any of the parties or both ask for amendments or termination. The Treaty revision explicitly remains in the domain of the parliamentary power, i.e. through the process of ratification. The process of termination is obviously left to each party to follow its rules for issuing a written notice to the other party, but it will get into force one year later.

\section{Conclusion: The Devil(s) in the Details}

Signing the BA in a politically and legally dubious and non-transparent way met no public resistance. Since the unfortunate events of 27 April 2017 (i.e. storming of the Parliament and victimization of Zaev and his party colleagues), 
the opposition had been practically silenced and discredited, under criminal charges for terrorism. Even before the BA was ratified in February 2018 with only 61 votes (out of 120 in total) and with the opposition's boycott, the government had already been on a fast track to reach an agreement with Greece. As soon as Skopje started with the PA's implementation (following the constitutional revision of February 2019), Sofia started reconsidering its positions.

In October 2019 the Bulgarian Parliament unanimously adopted Declaration that de facto reinterpreted the Treaty and imposed new demands for the accession process with N. Macedonia (Декларация 2019). According to the Declaration adopted just months after the PA's ratification and the consequent change of the Macedonian constitution, the Bulgarian parliamentarians called on its neighbor to fulfill eight listed demands, which could be summed up in one sentence: "the support of the National Parliament for European integration is not going to be given at the expense of fabrication of historical events, documents, and artifacts as well as of the role and perspectives of personalities from Bulgarian history". The declaration was followed by the Framework position of the Bulgarian government (Council of Ministers, 9 October 2019). The more concrete demands of the Bulgarian government had become known during the EU-Western Balkan (virtual) summit in Zagreb in May 2020, but the Macedonian government did not dare make them public. Finally, they reached the Macedonian public through the website of the Austrian Ministry of Foreign Affairs. The worst fears came true: Bulgaria insisted on its maximalist identity demands and imposed a biased interpretation of the Friendship treaty. Thus the outcome at the EU summit in December 2020 was not a surprise. The BA did not resolve any issue but opened a new Pandora's box.

Retrospectively speaking, one could assume that having been aware that for the majority of the Macedonian population the name change would be a far more traumatic event than any other concession, the Bulgarian government played tactically well by keeping silent and waiting for the major deal to be ratified and implemented. Once, there was a North Macedonia (and North Macedonians), Bulgaria could re-open the deal and press stronger, making direct comparisons with its Greek counterpart: if Greece could wait so long for your capitulation, and succeeded eventually, we are in no hurry - we are going to wait 30 years if necessary to get what we want.

The implementation of the PA meets hurdles but more importantly rests on the internal repressive measures. The implementation of the BA is another story: the pressures come from abroad, from Sofia but also from Brussels. Paradoxically, it was not Bulgarians but Czechs, Slovaks, and Austrians who rejected Bulgaria's 'historical' twist to enlargement criteria during the EU ministers' summit in December 2020, arguing that "We will not allow the [European] Union to be the judge of our shared history, how we identify ourselves, or the language we use. These issues belong to the parties concerned and we are here to support them" (Balkan Insight 18 December 2020). According to the media reports, the German EU presidency agreed to a compromise that included a crit- 
ical sentence imposed by Sofia as a last-ditch effort to nudge it into unblocking the start of EU accession talks for N. Macedonia. It read: "The Council recalls the Prespa Agreement between the Republic of North Macedonia and Greece and the Friendship, Good Neighborliness and Cooperation Agreement between the Republic of North Macedonia and Bulgaria and emphasizes the importance of continuing their implementation. These two important steps should put an end to all allegations based on a misinterpretation of history" (the emphasis added by the author) (IBNA, 17 December 2020).

Unlike the PA that has become a (geo)political holy bible (even for the opposition forces in the country), there has been an impression that the BA has met with overt public criticism and even patriotic reactions. This is particularly visible with the most ardent advocates of the PA, who had denounced any criticism of the PA as chauvinism, populism, nationalism, and even a pro-Russian stance. The re-born patriots even used hate speech and misogynistic vocabulary towards the Bulgarian foreign minister Zaharieva, which was duly noted in Sofia.

The process of interpretation of treaties' provisions (be they peace treaties or friendship treaties) is the most usual and delicate part of their implementation. This is a particularly delicate phase when the (quasi) legal (de facto, diplomatic) texts are intentionally written in a vague manner. Often that is the only way to reach an alleged 'consensus'.

According to some analysts, Sofia has upped the ante, "demanding blanket recognition by North Macedonia that its identity and language have Bulgarian foundations", while "these kinds of hardline tactics puzzle other EU members, but there is little evidence that any are prepared to push back against Bulgaria" (Bechev and Marusic 2020, p. 11). The problem is that the EU is still impotent as ever in resolving disputes in its backyard as it used to be thirty years ago. The enlargement is not a top priority issue for the failing Union amidst financial, political, and health crises.

It seems that the Macedonian side just exchanged one deadlock with another, which is far more serious and threatening than the Greek one. What shortsighted analysts do not see (or do not want to see) is that both 'disputes' over the Macedonian identity (name, language, history, culture and so) are just two sides of the same coin. The histories of international relations and international law do not know 'disputes' of such kind, and ones that could be 'resolved' in a legal way.

Due to their impotence to play the role of honest broker and normative power, the EU high officials rushed to greet the BA as "inspiration for the whole region" (European Western Balkans 2017). But even some Bulgarian analysts see the obvious that the friendship treaty is not written in the friendliest of ways, which lends itself to abuse when the bargaining power is unequal. Vassileva (2020) even notices the Orwellian traits in the joint expert commissions, which she dubs as Ministry of Truth. 
While the PA was supposed to bring closure to the NATO power puzzle in the Balkans (especially vis-à-vis Russian influence in Serbia) - and succeeded in doing so in March 2020, the EU negotiation process had not even been a serious option. The change of negotiation methodology de facto created a 'Greek (veto) factor' a plausible outcome not only concerning Macedonia's bid but more widely. Ever since any individual government could become 'Greece' i.e. has gained leverage to condition (i.e. blackmail) any potential member state because of any reason that goes beyond the Copenhagen criteria. On the other hand, as Nade Proeva (2020) notices correctly, the new methodology gibberish game has offered the greater powers a good alibi for further non-pursuance of its enlargement policy. Now the smaller and identity-sensitive members will do the job of blocking the expansion of the not quite functional Union.

Indeed the Macedonians are between a rock and a hard place: either to accept the idea of a "nation of many ethnicities" (as Greece and the Albanians prefer) or to embrace the offer and to 'admit' they are Bulgarians. The latter bears its own perils for the entire region. At the outset, both Greece and Bulgaria hoped to benefit from the old \& new Macedonian Question, but the equation has more than two unknowns. The possible scenarios are often spelled out by proxies (analysts, US senators, or think tanks) in various 'non-papers' with suggestions for re-drawing of the borders and (voluntary) division of the country. 


\section{References:}

Balkan Insight, "Macedonia, Bulgaria Sign Landmark Friendship Treaty", 1 August 2017, online

https://balkaninsight.com/2017/08/01/macedonia-bulgaria-signfriendship-treaty-08-01-2017/ (accessed on 15 February 2021).

Balkan Insight, "Czecks, Slovaks Reject Bulgaria's 'Historical' Twist to Enlargement Criteria", 18 December 2020, online

https://balkaninsight.com/2020/12/18/czecks-slovaks-reject-bulgariashistorical-twist-to-enlargement-criteria/ (accessed on 15 February 2021).

Bechev Dimitar and Marusic Damir, North Macedonia on the Threshold of Europe, The Atlantic Council, 2020, online

https://www.atlanticcouncil.org/wp-content/uploads/2020/12/NorthMacedonia-on-the-threshold-of-Europe.pdf (accessed on 15 February 2021).

Ćemalović, Uroš. "Towards a New Strategy for EU Enlargement - Between the Wish for an Encouragement, the Reality of the Fatigue and the Threat of a Dead End". EU and Comparative Law Issues and Challenges Series (ECLIC), 4 (September): 281-98, 2020.

Christopoulos Dimitris and Karpozilos Kostis, $10+1$ Questions \& Answers on the Macedonian Question, Rosa Luxemburg Stiftung Office in Greece, 2018, online https://www.rosalux.de/fileadmin/rls_uploads/pdfs/engl/ MAKEDONIKO_2019_\%CE\%95\%CE\%9D.pdf (accessed on 15 February 2021).

Chryssogelos Angelos and Stavrevska Elena, "The Prespa Agreement between Greece and North Macedonia and the Discordancies of EU Foreign Policy", European Foreign Affairs Review, vol. 24, no. 4, 2020.

Council of Ministers of the Republic of Bulgaria, Framework position on EU accession and the process of stabilization and association: Republic of $N$. Macedonia and Albania [in Bulgarian], 9 October 2019, online https:// www.gov.bg/bg/prestsentar/novini/ramkova-pozitsia?fbclid=IwAR3T 5YqWNSunLVYZ0FfixUEfLaS5b8hPm1V2hUYL1wZWtQVJBdjICQc_ RmY (accessed on 15 February 2021).

Декларация на Четиридесет и четвъртото Народно събрание на Република България във връзка с разширяването на Европейския съюз и Процеса на стабилизиране и асоцииране на Република Северна Македония и Република Албания, 10 October 2019, online https://www. parliament.bg/bg/news/ID/4920 (accessed on 21 February 2021).

$D W$, "Грозев: „Проблемот на Бугарија со Македонците е идеолошки“ [Bulgaria's problem with the Macedonians is ideological], 14 August 2009, online https://www.dw.com/mk/\%D0\%B3\%D1\%80\%D0\%BE\% D0\%B7\%D0\%B5\%D0\%B2-\%D0\%BF\%D1\%80\%D0\%BE\%D0\%B1\%D0 \%BB\%D0\%B5\%D0\%BC\%D0\%BE\%D1\%82-\%D0\%BD\%D0\%B0-\%D0 \%B1\%D1\%83\%D0\%B3\%D0\%B0\%D1\%80\%D0\%B8\%D1\%98\%D0\%B0- 
\%D1\%81\%D0\%BE-\%D0\%BC\%D0\%B0\%D0\%BA\%D0\%B5\%D0\%B4\%D0 \%BE\%D0\%BD\%D1\%86\%D0\%B8\%D1\%82\%D0\%B5-\%D0\%B5-\%D0\%B8 \%D0\%B4\%D0\%B5\%D0\%BE\%D0\%BB\%D0\%BE\%D1\%88\%D0\%BA\%D0\%B8/a-4563020 (accessed on 15 February 2021).

European Western Balkans, "Mogherini and Hahn on Treaty between Bulgaria and Macedonia", 1 August 2017, online https://europeanwesternbalkans. com/2017/08/01/mogherini-hahn-treaty-bulgaria-macedonia/ (accessed on 15 February 2021).

Final Agreement for the settlement of the differences as described in the United Nations Security Council Resolutions 817 (1993) and 845 (1993), the termination of the Interim Accord of 1995, and the establishment of a strategic partnership between the parties, 2018, online: https://www.un.org/pga/73/wp-content/ uploads/sites/53/2019/02/14-February-Letter-dated-14-February-2019. pdf (accessed on 23 March 2021).

Габер Виктор, Од објект до субјект: Македонија во меѓународните односи [From Object to Subject: Macedonia in International Relations], Скопје: ФEC, 2017, online: http://library.fes.de/pdf-files/bueros/skopje/14053.pdf (accessed on 16 February 2021).

Heraclides Alexis, "The settlement of the Greek-Macedonian naming dispute: the Prespa agreement", Security Dialogues, vol. 11, no. 2, 2020.

$I B N A$, “EU: Bulgaria's demands included in the conclusions on North Macedonia, with the help of Germany", 17 December 2020, online https://balkaneu. com/eu-bulgarias-demands-included-in-the-conclusions-on-northmacedonia-with-the-help-of-germany/ (accessed on 15 February 2021).

Ristevska Jordanova Malinka and Simonida Kacarska, EU - North Macedonia accession negotiations: the implications of the Bulgarian conditions, Skopje: EPI, 2020, online https://epi.org.mk/post/team/puttingcitizens-first-exploring-public-perceptions-of-administrative-servicesin?lang=en (accessed on 15 February 2021).

Karakamisheva Jovanovska, "Macedonian Constitutional Story", Iustinianus Primus Law Review, 2019, online:http://pf.ukim.edu.mk/wp-content/ uploads/2019/05/9.-Prof.-Karakamisheva-Jovanovska.pdf (accessed on 15 February 2021).

Kotzias Nikos, "OP/ED: The attitude of Bulgarian chauvinism in the Macedonian issue", IBNA, 2 December 2020, online https://balkaneu.com/op-ed-theattitude-of-bulgarian-chauvinism-in-the-macedonian-issue/ (accessed on 15 February 2021).

Loizides Neophytos (2020) "Symbolic right-sizing and Balkan nationalisms: the Macedonia name dispute and the Prespa Agreement", Irish Political Studies, 35:3, 492-508, DOI: 10.1080/07907184.2020.1816392.

Maatsch Aleksandra \& Anna Kurpiel (2021), "Between collective and particularistic interests. Ratification of the Prespa Agreement by national parliaments in Greece and North Macedonia", Southeast European and Black Sea Studies, 21:1, 53-75, DOI: 10.1080/14683857.2021.1877911. 
Макфакс, „ВМРО-ДПМНЕ почна да го условува договорот со Бугарија" [VMRO-DPMNE has started conditioning the agreement with Bulgaria], 21 July 2017, online https://makfax. com.mk/daily-new s/\% d 0\% b $2 \%$ d $0 \%$ bc \% d $1 \% 80 \%$ d $0 \%$ be$\%$ d $0 \%$ b $4 \%$ d $0 \%$ b f $\%$ d $0 \%$ b c $\%$ d $0 \%$ b d $\%$ d $0 \%$ b $5-$ $\%$ d $0 \%$ bf $\%$ d $0 \%$ be $\%$ d $1 \% 87 \%$ d $0 \%$ bd $\%$ d $0 \%$ b0 0 \% d $0 \%$ b $4 \%$ d $0 \%$ b $0-$ $\%$ d $0 \%$ b $3 \%$ d $0 \%$ b e - \% d $1 \% 83 \%$ d $1 \% 81 \%$ d $0 \%$ b b \% d $0-$ \%be\%d0\%b2\%d1\%83\%d0\%b2\%d0\%b0-\%d0\%b4\%d0\%be\%d0\%b3\%d0 $\%$ be $\%$ d0\% $2 \%$ d0\%be/ (accessed on 15 February 2021).

Маринов Чавдар, Македонското прашане од 1944 година до денес. Комунизмот и национализмот на Балканот [Macedonian Question since 1944. Communism and Nationalism in the Balkans], Скопје: ФИООМ, 2020.

META, "Zaev: The agreement with Bulgaria is a direct responsibility of Parliament", 21 July 2017, online https://meta.mk/en/zaev-the-treatywith-bulgaria-is-a-direct-responsibility-of-parliament/ (accessed on 16 February 2021).

Neofotistos P. Vasiliki (ed.), Macedonia and Identity Politics After the Prespa Agreement, NY and London: Routledge, 2021.

Нетпрес, „Груевски: Бугарија не го признава македонскиот јазик, сметаат дека е некаков бугарски дијалект" [Gruevski: Bulgaria does not recognize the Macedonian language, they argue it is a Bulgarian dialect], 8 July 2017, online http://netpress.com.mk/gruevski-bugarijane-go-priznava-makedonskiot-jazik-smetaat-deka-e-nekakov-bugarskidijalekt/ (accessed on 16 February 2021).

Nikodinovska Krstevska, Ana, "Observance of the rule of law and the Treaty of Prespa". In: International Academic Conference Bratislava Legal Forum 2020, 6-7 Feb 2020, Bratislava, Slovakia, online: http://eprints.ugd.edu. $\mathrm{mk} / 24468 /$ (accessed on 15 February 2021).

Novinite, "Rumen Radev: Protecting the Republic of North Macedonia's Air Space Is Bulgaria's National Duty and Responsibility", 4 December 2019, online https://www.novinite.com/articles/202027/Rumen+Radev $\% 3 \mathrm{~A}+$ Protecting+the+Republic+of+North+Macedonia $\%$ E2\%80\%99s+Ai $\mathrm{r}+$ Space+Is+Bulgaria\%E2\%80\%99s+National+Duty+and+Responsibility (accessed 15 February 2021).

Parliamentary Assembly of the Council of Europe, Resolution 2296 (2019) Postmonitoring dialogue with Bulgaria, online http://semantic-pace.net/ tools/pdf.aspx?doc=aHR0cDovL2Fzc2VtYmx5LmNvZS5pbnQvbncveG 1sL1hSZWYvWDJILURXLWV4dHIuYXNwP2ZpbGVpZD0yODA2MiZ sYW5nPUVO\& 